\title{
PENGARUH MEDIA TANAM DAN NUTRISI ORGANIK TANAMAN (NOT) LAU KAWAR TERHADAP PERTUMBUHAN DAN HASIL TANAMAN KACANG TANAH (Arachis hypogaea L.) VARIETAS TAKAR
}

\author{
Muhtar $^{1}$ dan Abdul Rahmi ${ }^{2}$ \\ ${ }^{1}$ Agroteknologi, Fakultas Pertanian, Universitas 17 Agustus 1945 Samarinda, Indonesia. \\ ${ }^{2}$ Dosen Fakultas Pertanian, Universitas 17 Agustus 1945 Samarinda 75124, Indonesia. \\ ${ }^{1}$ E-Mail: muhtar@untag-smd.ac.id \\ ${ }^{2}$ E-Mail: rahmi_untag@yahoo.co.id
}

\begin{abstract}
ABSTRAK
Pengaruh Media Tanam Dan Nutrisi Organik Tanaman (NOT) Lau Kawar Terhadap Pertumbuhan Dan Hasil Tanaman Kacang Tanah (Arachis hypogaea L.) Varietas Takar. Tujuan penelitian adalah untuk mengetahui pengaruh media tanam, aplikasi Nutrisi Organik Tanaman Lau Kawar dan interaksinya terhadap pertumbuhan dan hasil tanaman kacang tanah serta mendapatkan media tanam dan Nutrisi Organik Tanaman. kacang.

Penelitian ini dilakukan dari Maret hingga Juni 2019 di Desa Sungai Pinang Dalam, Kabupaten Sungai Pinang, Samarinda, Provinsi Kalimantan Timur.

Penelitian ini menggunakan Rancangan Acak Lengkap (RAL) dalam Percobaan Faktorial 3 x 3 dan 5 replikat. Faktor pertama adalah media tanam (M) yang terdiri 3 level, yaitu: media tanam humus (m0), media tanam humus + kotoran kambing 2: $1(\mathrm{~m} 1)$, dan media tanam topsoil + kotoran kambing + bahan bakar kulit 2: 1: 1 (m2). Faktor kedua adalah konsentrasi Gizi Organik Tanaman Lau Kawar (P) yang terdiri dari 3 level, yaitu: tanpa Gizi Organik Tumbuhan Lau Kawar (p0), 2 ml 1-1 air (p1) dan 4 ml 1-1 air (p2) . Hasil percobaan menunjukkan bahwa perlakuan media tanam dan aplikasi Nutrisi Organik Tumbuhan Lau Kawaraplikasi dan interaksinya tidak signifikan pada semua parameter pengamatan, dan media tanam dan konsentrasi Nutrisi Organik Tumbuhan Lau Kawar tidak sesuai untuk pertumbuhan dan hasil tanaman kacang tanah.
\end{abstract}

Kata kunci : Kacang tanah, Media Tanam, Nutrisi Organik Tanaman Lau Kawar.

\begin{abstract}
The Effect of Planting Media and Plant Organic NutritionLau Kawar Application On the Growth and Yield of Peanut Plants (Arachis hypogaea L.)Takar 2 Variety. The researchof this study was to determine the effect of planting media,Plant Organic Nutrition Lau Kawar application and its interaction on the growth and yield of peanut plants and also to obtain planting media and Plant Organic NutritionLau Kawar concentrations for obtaining the best growth and yield of peanut.

The research was conducted from March to June 2019 in the Sungai Pinang Dalam Village, Sungai Pinang District, Samarinda, East Kalimantan Province.

The research used a Completely Randomized Design (CRD) in Factorial Experiments $3 \times 3$ and 5 replicatons. The first factor is the planting medium $(M)$ which consisting 3 levels, namely: planting media of the topsoil $(\mathrm{m} 0)$, planting media of topsoil + goat manure 2: $1(\mathrm{ml})$, and planting media of topsoil + goat manure + fuel husk 2: 1: 1 ( $(\mathrm{m} 2)$. The second factor was the Plant Organic Nutrition Lau Kawar $(P)$ concentration which consisting 3 levels, namely: without Plant Organic Nutrition Lau Kawar (p0), 2 ml $l^{-1}$ water (p1) and $4 \mathrm{ml} \mathrm{l}^{-1}$ water (p2).

The results of experiment showed that the treatment of planting media and Plant Organic Nutrition Lau Kawarapplicationand its interaction no significant on the all observational parameters, and the planting media and concentrations of Plant Organic Nutrition Lau Kawarwere not suitable for growth and yield of peanut plants.
\end{abstract}

Key words : Media of Planting, Peanut, Plant Organic Nutrition Lau Kawar. 


\section{PENDAHULUAN}

Kacang tanah merupakan tanaman pangan yang mempunyai nilai ekonomi tinggi karena kandungan gizinya terutama protein dan lemak yang tinggi. Kebutuhan kacang tanah dari tahun ke tahun terus meningkat sejalan dengan bertambahnya jumlah penduduk, kebutuhan gizi masyarakat, diversifikasi pangan, serta meningkatnya kapasitas industri pakan dan makanan di Indonesia. Menurut Badan Pusat Statistik (2017) bahwa produksi kacang tanah di Provinsi Kalimantan Timur pada tahun 2015 adalah 1.127 Megagram, pada tahun 2016 menurun menjadi 1.008 Megagram, dan pada tahun 2017 kembali mengalami penurunan produktivitas menjadi 950 Megagram atau turun 6,11 persen dari produksi tahun 2016.

Produktivitas kacang tanah di Kalimantan Timur ini masih tergolong rendah jika dibandingkan dengan provinsi-provinsi lain yang ada di Indonesia pada umumnya seperti Kalimantan Selatan yang mencapai 9.121 Megagram pada tahun 2015 dan mengalami kenaikan produksi ditahun 2016 menjadi 9.941 Megagram. Di Nusa Tenggara Barat mencapai 31.142 Megagram di tahun 2015 dan meningkat di tahun 2016 menjadi 33.749 Megagram. Menurunnya produktivitas kacang tanah di Kalimantan Timur salah satunya disebabkan oleh kesuburan tanah yang rendah dan penggunaan pupuk kimia (Urea, TSP, dan KCL) secara berkepanjangan yang tidak diimbangi dengan pupuk organik, sehingga dapat merusak tanah. Ketersediaan unsur hara didalam tanah merupakan salah satu faktor pendukung pertumbuhan tanaman disamping faktor fisik dan biologi tanah. Kemampuan tanah dalam menyediakan unsur hara sangat ditentukan oleh kualitas dan jumlah bahan organik dalam mengikat partikel - partikel tanah.

Pemupukan sangat berpengaruh dalam peningkatan produktivitas tanaman, namun pemberian pupuk kimia dalam jangka panjang dikhawatirkan dapat merusak sifat fisik, kimia dan biologi tanah. Untuk mengatasi hal tersebut, diperlukan suatu sistem pemupukan yang ramah terhadap lingkungan dan aman bagi lingkungan. Pupuk organik dapat menjadi salah satu alternatif yang tepat dalam mengatasi permasalahan tersebut mengingat fungsinya yang dapat memperbaiki sifat fisik tanah sehingga nutrisi yang dibutuhkan tanaman dapat tercukupi.

Pupuk kandang kambing merupakan salah satu pupuk organik yang baik bagi tanaman. Kombinasi yang baik antara pupuk kandang dengan media tanam yang lain dapat mempengaruhi pertumbuhan tanaman. Selain sebagai media tanam, pupuk kandang kambing mengandung unsur hara sehingga dapat menyediakan nutrisi bagi tanaman. Media tanam organik yang lain selain pupuk kandang antara lain sekam bakar. Media sekam bakar berfungsi menjaga kondisi tanah tetap gembur karena memiliki porositas tinggi dan ringan. Selain itu pula sekam bakar dapat mempertahankan kelembapan dan meningkatkan daya serap dan daya ikat tanah terhadap air (Azzamy, 2015).

Nutrisi organik tanaman (NOT) Lau Kawar adalah salah satu jenis bahan 
organik yang dapat digunakan untuk meningkatkan produktivitas tanaman kacang tanah. Hal ini didukung karena bahan organik tersebut mengandung unsur hara makro dan mikro yang cukup tinggi sebagai hasil senyawa organik bahan alami yang mengandung sel-sel hidup aktif dan aman bagi lingkungan dan pemakai. Bentuknya yang berupa cairan dapat mempermudah tanaman dalam menyerap unsur hara yang terkandung di dalamnya dibandingkan dengan pupuk lain yang berbentuk padat. Dalam pengaplikasiannya, selain diberikan melalui tanah yang kemudian diserap oleh akar tanaman dapat juga diaplikasikan melalui daun tanaman guna mendukung penyerapan unsur hara secara optimal.

Tujuan penelitian adalah : (1) untuk mengetahui pengaruh media tanam dan pemberian NOT Lau Kawar serta interaksinya terhadap pertumbuhan dan hasil tanaman kacang tanah; dan (2) untuk memperoleh media tanam dan konsentrasi NOT Lau Kawar yang tepat untuk budidaya tanaman kacang tanah.

\section{METODA PENELITIAN}

\subsection{Tempat dan Waktu}

Penelitian ini dilaksanakan di Kelurahan Sungai Pinang Dalam, Kecamatan Sungai Pinang Samarinda. Pada bulan Maret-Juni 2019.

\subsection{Bahan dan Alat}

Bahan yang digunakan antara lain : tanah lapisan atas, benih kacang tanah varietas Takar 2, polibag berukuran $40 \mathrm{~cm}$ x $40 \mathrm{~cm}$, pupuk kandang kambing, sekam bakar, NOT Lau Kawar, dan pestisida nabati bawang putih.
Alat yang digunakan adalah cangkul, timbangan analitik, timbangan manual, ayakan berukuran $1 \mathrm{~cm} \mathrm{x} 1$ $\mathrm{cm}$, ember plastik, gembor, sprayer, label perlakuan, meteran dan alat tulis.

\subsection{Rancangan Penelitian}

Penelitian ini dilaksanakan dengan menggunakan Rancangan Acak Lengkap (RAL) dengan pola faktorial 3 x 3 yang diulang sebanyak 5 kali. Faktor pertama adalah media tanam (M) terdiri atas 3 macam yaitu : media tanam berupa tanah lapisan atas(m0), media tanam berupa campuran tanah dan pupuk kandang kambing $2: 1(\mathrm{~m} 1)$, dan media tanam berupa campuran tanah, pupuk kandang kambing, dan sekam bakar $2: 1: 1(\mathrm{~m} 2)$. Faktor kedua adalah konsentrasi NOT Lau Kawar (P) terdiri dari 3 taraf yaitu :tanpa pemberian NOT Lau Kawar (p0), konsentrasi $2 \mathrm{mll}^{-1}$ air (p1), dan konsentrasi $4 \mathrm{mll}^{-1}$ air (p2).

\subsection{Pelaksanan Penelitian}

Tahapan kegiatan penelitian yang dilaksanakan meliputi : persiapan lokasi penelitian, persiapan media tanah, penanaman benih, pemberian NOT Lau Kawar

Pemberian perlakuan NOT Lau Kawar disesuaikan dengan perlakuan, yang dilakukan pada pagi hari antara pukul 08.00 - 09.30 Wita dengan cara menyemprotkan larutan pupuk ke bagian daun dan batang tanaman. Penyemprotan dilakukan sebanyak 3 kali yaitu pada saat tanaman berumur 3 , 5, dan 7 minggu setelah tanam, dan pemeliharaan tanaman meliputi: penyiraman, penyiangan gulma, pembumbunan, pengendalian hama dengan cara menyemprotkan larutan 
pestisida nabati berbahan dasar bawang putih yang dilakukan antara pukul 07.00 - 10.00 Wita dengan cara menyemprotkan ke bagian daun dan batang tanaman sebanyak 3 kali, yaitu pada umur 30, 45, dan 60 hari setelah tanam.

Pemananen dilakukan apabila tanaman menunjukkan gejala-gejala sebagai berikut : batang tanaman mulai mengeras, daun mulai menguning dan berguguran, Polong terisi penuh, mengeras, berwarna cokelat dan kehitaman. Panen dilakukan pada pagi hari terhadap polong kacang tanah yang telah memenuhi kriteria panen.

\subsection{Pengambilan Data}

Data utama : tinggi tanamanpada saat tanaman berumur 30, 45, dan 60 hari setelah tanam, umur tanaman saat panen (hari setelah tanam), Jumlah polong per tanaman (buah), persentase polong isi per tanaman $(\%)$, berat 50 biji kering (g), danproduksi biji kering (g).

Data penunjang :

a. Analisis sifat kimia tanah, pupuk kandang kambing, sekam bakar, dan NOT Lau Kawar di Laboratorium Tanah Fakultas Pertanian Universitas Mulawarman.

b. Keadaan hari dan curah hujan, suhu udara, kelembaban udara relatif dan penyinaran matahari dari bulan Maret - Juni 2019 yang diperoleh dari Badan Meteorologi dan Geofisika Stasiun Temindung Samarinda.

\subsection{Analisis Data}

Data yang telah dikumpulkan dari hasil pengamatan selanjutnya dianalisis dengan sidik ragam (Steel dan Torrie 1991).berpengaruh nyata dimana $\mathrm{F}$ hitung $>\mathrm{F}$ tabel $5 \%$ dan berpengaruh sangat nyata dimana $\mathrm{F}$ hitung > F tabel $1 \%$,maka untuk membandingkan dua rata-rata perlakuan dilakukan uji lanjutan dengan menggunakan Uji Beda Nyata Terkecil (BNT) pada taraf $5 \%$.

\section{HASIL PENELITIAN DAN PEMBAHASAN}

\subsection{Hasil}

Hasil sidik ragam menunjukkan bahwa perlakuan media tanam berpengaruh tidak nyata terhadap tinggi tanaman pada umur 30, 45 dan 60 hari setelah tanam, umur tanaman saat panen, jumlah polong per tanaman, persentase polong isi, berat 50 biji kering, dan produksi biji kering tanaman kacang tanah varietas Takar 2 .

Hasil sidik ragam menunjukkan bahwa perlakuan pemberian NOT Lau Kawar berpengaruh tidak nyata terhadap tinggi tanaman pada umur 30, 45 dan 60 hari setelah tanam, umur tanaman saat panen, jumlah polong per tanaman, persentase polong isi, berat 50 biji kering, dan produksi biji kering tanaman kacan tanah varietas Takar 2 .

Hasil sidik ragam menunjukkan bahwa interaksi antara faktor media tanam dan faktor pemberian NOT Lau Kawar berpengaruh tidak nyata terhadap tinggi tanaman pada umur 30, 45 dan 60 hari setelah tanam, umur tanaman saat panen, jumlah polong per tanaman, persentase polong isi, berat 50 biji kering, dan produksi biji kering tanaman kacang tanah varietas Takar 2 .

Rekapitulasi hasil penelitian pengaruh media tanam dan NOT Lau Kawar serta interaksinya terhadap pertumbuhan dan hasil tanaman kacang tanah disajikan pada Tabel 1. 
Tabel 1. Rekapitulasi Hasil Penelitian Pengaruh Media Tanam dan Pemberian NOT Lau Kawar serta Interaksinya terhadap Pertumbuhan dan Hasil Tanaman Kacang Tanah Varietas Takar 2

\begin{tabular}{|c|c|c|c|c|c|c|c|c|}
\hline Faktor-Faktor & Tingg & Tanam & $(\mathrm{cm})$ & Umur & Jumlah & Persentase & Berat & Prod \\
\hline Perlakuan & $\begin{array}{c}30 \\
\mathrm{HST}\end{array}$ & $\begin{array}{c}45 \\
\text { HST }\end{array}$ & $\begin{array}{c}60 \\
\text { HST }\end{array}$ & $\begin{array}{l}\text { Saat } \\
\text { Panen } \\
\text { (HST) }\end{array}$ & $\begin{array}{l}\text { Polong } \\
\text { (buah } \\
\tan ^{-1} \text { ) }\end{array}$ & $\begin{array}{l}\text { Polong Isi } \\
(\%)\end{array}$ & $\begin{array}{l}50 \text { Biji } \\
\text { Kering } \\
\quad(g)\end{array}$ & $\begin{array}{c}\text { Biji } \\
\text { Kering } \\
(\mathrm{g} \text { tan-1) }\end{array}$ \\
\hline $\begin{array}{l}\text { Faktor Media } \\
\text { Tanam } \\
\text { (M) }\end{array}$ & tn & tn & tn & tn & tn & tn & tn & tn \\
\hline $\begin{array}{l}\text { Tanah Lapisan } \\
\text { Atas (m0) }\end{array}$ & 29,39 & 44,82 & 51,69 & 85,13 & 26,87 & 92,34 & 22,34 & 31,70 \\
\hline $\begin{array}{l}\text { Tanah + Pukan } \\
\text { Kambing (m1) } \\
\text { Tanah+Pukan }\end{array}$ & 26,59 & 45,28 & 52,99 & 84,53 & 27,07 & 92,69 & 22,85 & 32,55 \\
\hline $\begin{array}{l}\text { Kambing+Sekam } \\
\text { Bakar }(\mathrm{m} 2)\end{array}$ & 29,28 & 45,81 & 52,51 & 83,93 & 28,80 & 94,15 & 23,53 & 32,85 \\
\hline $\begin{array}{l}\text { Faktor NOT } \\
\text { Lau Kawar (P) }\end{array}$ & tn & tn & tn & tn & tn & tn & tn & tn \\
\hline Tanpa NOT (p0) & 28,43 & 44,58 & 52,63 & 84,20 & 27,00 & 92,86 & 22,89 & 32,35 \\
\hline $\begin{array}{l}2 \mathrm{ml} \mathrm{l}^{-1} \text { air }(\mathrm{p} 1) \\
4 \mathrm{ml} \mathrm{l}^{-1} \text { air }(\mathrm{p} 2)\end{array}$ & $\begin{array}{l}28,91 \\
27,93\end{array}$ & $\begin{array}{l}45,97 \\
45,36\end{array}$ & $\begin{array}{l}52,92 \\
62,64\end{array}$ & $\begin{array}{l}84,33 \\
85,07\end{array}$ & $\begin{array}{l}27,80 \\
27,09\end{array}$ & $\begin{array}{l}93,25 \\
93,07\end{array}$ & $\begin{array}{l}22,99 \\
22,82\end{array}$ & $\begin{array}{l}32,56 \\
32,19\end{array}$ \\
\hline $\begin{array}{l}\text { Interaksi } \\
(\mathbf{M} \times \mathbf{P})\end{array}$ & tn & tn & tn & tn & tn & tn & tn & tn \\
\hline $\mathrm{m} 0 \mathrm{p} 0$ & 29,04 & 42,60 & 51,02 & 84,80 & 26,60 & 92,35 & 22,34 & 31,29 \\
\hline $\mathrm{m} 0 \mathrm{p} 1$ & 30,54 & 45,88 & 51,58 & 83,80 & 27,40 & 92,47 & 21,96 & 31,86 \\
\hline $\mathrm{m} 0 \mathrm{p} 2$ & 28,60 & 45,98 & 52,46 & 86,80 & 26,60 & 92,20 & 22,71 & 31,96 \\
\hline $\mathrm{m} 1 \mathrm{p} 0$ & 26,92 & 44,88 & 52,56 & 84,20 & 26,20 & 92,58 & 22,20 & 32,50 \\
\hline $\mathrm{m} 1 \mathrm{p} 1$ & 26,66 & 44,52 & 51,76 & 85,60 & 27,40 & 92,25 & 23,66 & 32,86 \\
\hline $\mathrm{m} 1 \mathrm{p} 2$ & 26,20 & 46,44 & 54,66 & 83,80 & 27,60 & 93,23 & 22,68 & 32,28 \\
\hline $\mathrm{m} 2 \mathrm{p} 0$ & 29,32 & 46,26 & 54,32 & 83,60 & 28,20 & 93,64 & 24,15 & 33,26 \\
\hline $\mathrm{m} 2 \mathrm{p} 1$ & 29,54 & 47,50 & 55,42 & 83,60 & 28,60 & 95,02 & 23,36 & 32,95 \\
\hline $\mathrm{m} 2 \mathrm{p} 2$ & 28,98 & 43,66 & 50,80 & 84,60 & 29,60 & 93,79 & 22,68 & 32,33 \\
\hline
\end{tabular}

Keterangan $:$ tn $=$ berpengaruh tidak nyata; HST = hari setelah tanam; dan Pukan = pupuk kandang kambing

\subsection{Pembahasan}

Hasil penelitian yang disajikan pada Tabel 1 (rekapitulasi hasil penelitian) menunjukkan adanya kecenderungan bahwa perlakuan media tanam berupa campuran tanah, pupuk kandang kambing dan sekam bakar (m2) menghasilkan umur tanaman saat panen yang lebih cepat, komponen hasil (jumlah polong, persentase polong isi, berat 50 biji kering) dan produksi biji kering yang lebih baik dibandingkan perlakuan media tanam berupa tanah $(\mathrm{m} 0)$ dan perlakuan media tanam berupa campuran tanah dan pupuk kandang kambing (m1).

Tidak adanya pengaruh yang nyata dari perlakuan media tanam (media tanah (m0), media tanam berupa campuran tanah dan pupuk kandang kambing (m1), dan media tanam berupa campuran tanah, pupuk kandang kambing dan sekam bakar (m2) terhadap pertumbuhan dan hasil kacang tanah tersebut dapat disebabkan oleh beberapa faktor antara lain kandungan unsur hara dalam media tanam berupa tanah berdasarkan hasil analisis laboratorium (Lampiran Tabel 9) yaitu sebagai berikut : 3,15\% C-organik, $58,70 \%$ kejenuhan basa (tergolong tinggi), $0,21 \% \mathrm{~N}$ total, 94,71 ppm K tersedia; $0,39 \mathrm{me} / 100 \mathrm{~g}$ tanah $\mathrm{K}^{+}$dan $0,45 \mathrm{me} / 100 \mathrm{~g}$ tanah $\mathrm{Na}^{+}$(tergolong sedang); 4,77 me/100 g tanah $\mathrm{Ca}^{++}$dan $0,82 \mathrm{me} / 100 \mathrm{~g}$ tanah $\mathrm{Mg}^{++}$dan 10,94 
me/100 g tanah KTK (tergolong rendah) diduga dapat memenuhi kebutuhan unsur hara tanaman kacang tanah, sehingga pemberian pupuk kandang kambing dan sekam bakar tidak memberikan pengaruh yang nyata.

Pemberian pupuk kandang kambing dan sekam bakar secara bahan campuran pada media tanam tidak memberikan pengaruh yang nyata terhadap pertumbuhan dan hasil tanaman kacang tanah disebabkan karena kedua bahan organik tersebut merupakan bahan yang lambat mengalami dekomposisi, sehingga lambat dalam menambah unsur hara bagi tanaman. Seperti dinyatakan oleh Musnamar (2003) bahwa bahan organik padat merupakan bahan organik yang slow release yaitu unsur hara dalam bahan organik tersebut dilepaskan secara perlahan-lahan dalam jangka waktu tertentu.

Keadaan cuaca selama penelitian dilaksanakan lebih banyak hujan yaitu antara 17 - 20 hari hujan dalam 1 bulan dan penyinaran matahari setiap hari hanya berkisar antara 3,10 - 4,50 jam saja (Tabel 1). Keadaan ini sangat berpengaruh terhadap proses metabolisme/fotosintesis dalam tubuh tanaman, karena intensitas cahaya yang rendah sehingga proses fotosintesis menjadi tidak maksimal dan akan berpengaruh terhadap pertumbuhan dan perkembangan tanaman kacang tanah. Seperti dinyatakan oleh Suprapto (2004) bahwa Intensitas cahaya sangat berpengaruh pada proses fotosintesis dan respirasi. Kanopi tanaman sangat respons terhadap meningkatnya intensitas cahaya. Penyinaran $60 \%$ cahaya matahari pada tanaman berumur 60 hari setelah kecambah merupakan saat kritis bagi tanaman. Intensitas cahaya yang rendah pada saat berbunga akan menghambat pertumbuhan vegetatif. Pada fase pembungaan, saat terbukanya bunga dan jumlah bunga yang terbentuk sangat tergantung pada cahaya. Intensitas cahaya yang rendah pada saat pembentukan ginofor akan mengurangi jumlah ginofor. Di samping itu, rendahnya intensitas penyinaran pada masa pengisian polong akan menurunkan jumlah dan bobot polong sehingga meningkatkan jumlah polong hampa.

Hasil penelitian yang disajikan pada Tabel 1 menunjukkan adanya kecenderungan bahwa pemberian NOT Lau Kawar dengan konsentrasi $2 \mathrm{ml} \mathrm{l}^{-1}$ air (p1) dan $4 \mathrm{ml} \mathrm{l}^{-1}$ air (p2) cenderung menghasilkan pertumbuhan tanaman yang lebih tinggi dan produksi biji kering yang lebih tinggi dibandingkan dengan perlakuan tanpa pemberian NOT Lau Kawar.

Tidak adanya pengaruh yang nyata dari pemberian NOT Lau Kawar terhadap pertumbuhan dan hasil kacang tanah tersebut dapat disebabkan oleh beberapa faktor antara lain perlakuan pemberian berbagai konsentrasi NOT Lau Kawar tersebut belum sesuai dengan keperluan tanaman kacang tanah (konsentrasi yang diberikan masih terlalu rendah). Seperti dinyatakan oleh Lingga dan Marsono (2003) bahwa konsentrasi pupuk daun yang diberikan harus sesuai dengan kebutuhan tanaman, jangan berlebihan atau jangan terlalu rendah. Selanjutnya dinyatakan oleh Prihmantoro (1999) bahwa efektivitas pemberian pupuk sangat tergantung pada saat pupuk diberikan, pemberian pupuk yang tidak tepat atau tidak sesuai dengan kebutuhan tanaman hanya merupakan pemborosan saja.

Selama penelitian dilaksanakan keadaan cuaca lebih banyak hujan dan penyinaran matahari setiap hari hanya berkisar antara 3,10 - 4,50 jam saja, keadaan ini berpengaruh terhadap penyerapan unsur hara dari NOT Lau Kawar yang diberikan dalam hal ini penyerapan oleh daun kacang tanah tidak maksimal. Seperti dinyatakan oleh 
Dwidjoseputro (1998) bahwa mekanisme membuka dan menutupnya stomata berkaitan dengan perubahan turgor, dan perubahan turgor tersebut adalah akibat perubahan nilai osmosis pada isi air selsel penutup pada stomata. Jika sel-sel penutup tidak mendapatkan sinar matahari, maka menurunlah $\mathrm{pH}$, dan ini akan menyebabkan enzim fosforilase untuk mengadakan kegiatan merubah glukosa menjadi amilum. Keadaan ini menyebabkan turunnya nilai osmosis dan berkurangnya turgor, sehingga mengakibatkan berkurangnya pembukaan stomata (stomata tidak membuka secara maksimal). Keadaan ini menyebabkan penyerapan unsur hara dari NOT Lau Kawar yang diberikan tidak maksimal.

Hasil sidik ragam menunjukkan bahwa interaksi antara faktor media tanam dan faktor pemberian NOT Lau Kawar berpengaruh tidak nyata terhadap tinggi tanaman pada umur 30, 45 dan 60 hari setelah tanam, umur tanaman saat panen, jumlah polong per tanaman, persentase polong isi, berat 50 biji kering, dan produksi biji kering tanaman kacang tanah varietas Takar 2. Hal ini menunjukkan bahwa antara faktor media tanam dan dan faktor konsentrasi NOT Lau Kawar tidak secara bersama-sama dalam mempengaruhi pertumbuhan dan hasil tanaman kacang tanah. Keadaan ini juga didukung oleh pengaruh mandiri dari kedua faktor perlakuan yang juga tidak nyata. Seperti dikemukakan oleh Steel dan Torrie (1991), bahwa apabila pengaruh interaksi berbeda tidak nyata maka disimpulkan bahwa diantara faktor perlakuan tersebut bertindak bebas satu sama lainnya. Selanjutnya dinyatakan oleh Gomez dan Gomez (1995), bahwa dua faktor dikatakan berinteraksi apabila pengaruh suatu faktor perlakuan berubah pada saat perubahan taraf faktor perlakuan lainnya.

Secara umum hasil penelitian yang disajikan pada Tabel 1 (rekapitulasi hasil penelitian) menunjukkan bahwa perlakuan media tanam campuran tanah, pupuk kandang kambing dan sekam bakar yang dikombinasikan berbagai konsentrasi NOT Lau Kawar (m2p0, $\mathrm{m} 2 \mathrm{p} 1$, dan $\mathrm{m} 2 \mathrm{p} 2$ ) menghasilkan produksi biji kering kacang tanah yaitu berturutturut 33,26 $\mathrm{g}_{\text {tanaman }}{ }^{-1}, 32,95 \mathrm{~g}$ tanaman 1, dan 32,33 g tanaman $^{-1}$; Produksi biji kering tersebut adalah lebih tinggi dibandingkan dengan produksi biji kering kacang tanah yang dihasilkan pada perlakuan media tanam berupa tanah yang dikombinasikan berbagai konsentrasi NOT Lau Kawar (m0p0, m0p1, dan m0p2) yaitu berturut-turut 31,29 $\mathrm{g} \mathrm{tanaman}^{-1} ; 31,86 \mathrm{~g}$ tanaman $^{-1}$; dan 31,96 g tanaman ${ }^{-1}$; dan perlakuan media tanam campuran tanah dan pupuk kandang kambing yang dikombinasikan berbagai konsentrasi NOT Lau Kawar (m1p0, m1p1, dan m1p2) yaitu berturutturut 32,50 $\mathrm{g}$ tanaman $^{-1} ; 32,86 \mathrm{~g}$ tanaman 1; dan 32,28 g tanaman $^{-1}$.

\section{KESIMPULAN}

Berdasarkan hasil penelitian dan pembahasan dapat disimpulkan yaitu : Perlakuan media tanam berpengaruh tidak nyata terhadap tinggi tanaman pada umur 30, 45, dan 60 hari setelah tanam, umur tanaman saat panen, jumlah polong, persentase polong isi, berat 50 biji kering dan produksi biji kering per tanaman.

Perlakuan pemberian NOT Lau Kawar berpengaruh tidak nyata terhadap tinggi tanaman pada umur 30, 45, dan 60 hari setelah tanam, umur tanaman saat panen, jumlah polong, persentase polong 
isi, berat 50 biji kering dan produksi biji kering per tanaman.

Perlakuan interaksi antara media tanam dan pemberian NOT Lau Kawar berpengaruh tidak nyata terhadap tinggi tanaman pada umur 30, 45, dan 60 hari setelah tanam, umur tanaman saat panen, jumlah polong, persentase polong isi, berat 50 biji kering dan produksi biji kering per tanaman.

Belum diperoleh media tanam dan konsentrasi NOT Lau Kawar yang sesuai untuk pertumbuhan dan hasil tanaman kacang tanah.

\section{DAFTAR PUSTAKA}

Azzamy, (2015). Manfaat Arang Sekam sebagai Media Tanam. http/mitalon com/manfaat arang sekam sebagai media tanam.

Badan Pusat Statistik. (2017). Data Produksi Kacang Tanah Nasional, BPS, Jakarta.
Dwidjoseputro, D. (1998). Pengantar Fisiologi Tumbuhan. Jakarta: Gramedia.

Gomez, K.A dan A.A. Gomez . (1995). Prosedur Statistik untuk Penelitian Pertanian (Terjemahan A. Sjamsuddin dan J.S Baharsyah). Edisi Kedua. Jakarta: UI Press.

Lingga, P dan Marsono. (2003). Petunjuk Penggunaan Pupuk. Jakarta: Penebar Swadaya.

Musnamar, E.I. (2003). Pembuatan dan Aplikasi Pupuk Organik Padat. Jakarta: Penebar Swadaya.

Prihmantoro, H. 1999. Memupuk Tanaman Sayuran. Jakarta: Penebar Swadaya.

Steel, R.G.D dan J. H. Torrie. (1991). Prinsip dan Prosedur Statistika Suatu Pendekatan Biometrik. Jakarta: Gramedia Pustaka Utama.

Suprapto, H. S. (2004). Bertanam Kacang Tanah. Jakarta: Penebar Swad 